Industry, the State, and Public Policy in Mexico 
Latin American Monographs, No. 66

Institute of Latin American Studies

The University of Texas at Austin 


\section{INDUSTRY, THE STATE, AND PUBLIC POLICY IN MEXICO}

By Dale Story

ד্ University of Texas Press, Austin 


\section{Library of Congress Cataloging in Publication Data}

Story, Dale, 1950-

Industry, the state, and public policy in Mexico

(Latin American monographs / Institute of Latin

American Studies, the University of Texas at Austin ; no. 66)

Bibliography: $p$.

Includes index.

1. Industry and state-Mexico. 2. Industrialists-Mexico.

I. Title. II. Series: Latin American monographs (University of Texas at Austin. Institute of Latin American Studies) ; no. 66

HD3616.M43S76 $1986 \quad 338.972 \quad 85-13363$

ISBN 0-292-73837-4

Copyright $\odot 1986$ by the University of Texas Press

All rights reserved

Printed in the United States of America

First edition, 1986

Requests for permission to reproduce material from

this work should be sent to

Permissions

University of Texas Press

P.O. Box 7819

Austin, Texas 78713

ISBN 978-0-292-76646-4 (library e-book)

ISBN 978-0-292-76647-1 (individual e-book) 
To my parents 
THIS PAGE INTENTIONALLY LEFT BLANK 